\title{
IMMIGRANT SOCIAL INCLUSION IN EUROPE: A DESCRIPTIVE INVESTIGATION
}

\author{
Dionyssis Balourdos ${ }^{1}$ (D), Maria Petraki ${ }^{2}$ \\ ${ }^{1}$ Director of Research Emeritus \\ National Centre for Social Research (EKKE) \\ Str. Kratinou 9 \& Athinas, P.C. 105 52, Athens: Greece \\ dbalourdos@ekke.gr \\ ${ }^{2}$ Ministry of Justice, Athens Court of Appeals \\ 14, Kyrillou Loukareos str., P.C. 115 22, Athens: Greece \\ Hellenic Open University \\ 4-6, Gravias str., P.C. 106 78, Athens: Greece \\ mariakpetraki@gmail.com
}

\begin{abstract}
This paper represents an empirical investigation into the risk of poverty or social exclusion facing immigrants across Europe. The methodological approach is based on the set of 'Zaragoza indicators', in the domain of social inclusion, together with some proposed additional ones: income distribution and monetary poverty, material deprivation, in-work poverty, child poverty and risk of poverty or social exclusion. The main research question concerns whether immigrants/third-country nationals and nationals constitute two rather distinct groups in terms of exposure to poverty or social exclusion. Mainly using data from the EU-SILC Survey, we find that third-country nationals are severely disadvantaged in most countries, and are occasionally exposed to risks multiple times higher than nationals. There are European countries with similar immigrant populations in which these immigrants experience less favorable outcomes compared to other populations in other countries. Comparative analysis allows us to test the significance of different welfare systems in protecting vulnerable groups such as immigrants, using Eurostat statistics and the Migrant Integration Policy Index (MIPEX). In a cross-country analysis, taking demographic and macro-economic differences into account, results show that the impact of social expenditure on poverty is not significant when it comes to protecting third-country nationals.
\end{abstract}

Keywords: immigrants, poverty, social exclusion, social expenditure, Zaragoza indicators.

\section{Introduction}

Immigration is once again at the forefront of policy discourses in many European countries, and ranks among the greatest concerns in European policy debates, in recent years especially. The countries that have attracted the strongest recent migratory inflows (i.e. Greece, Spain, Italy and other southern European countries) are also among those affected cruelly. However, steady increases in unemployment and cuts in personal income and public services create new poor groups including young people, children and the working poor, and especially those with an immigrant background. Other, more-prosperous countries receiving immigrants (e.g. France, Germany, The 
Netherlands or Sweden) have experienced severe pressure and deteriorating economic growth merely due to worsening public finances.

Migration seems to have an impact on many different aspects of destination societies and one key challenge for both policymakers and scholars is then likely to be the achievement of a higher degree of integration of immigrants. Migration has also had notable social and economic implications for many European countries, inter alia in terms of poverty risk and social exclusion. Many empirical studies acknowledge the high-risk status of immigrants as a group, along with problems with integration and with gaining opportunities from the receiving country.

While challenges and debates are ongoing, very few studies have examined immigrant integration in quantitative terms. Indexes comparing integration policies, most notably the Migrant Integration Policy Index (MIPEX) do exist, but with minor exceptions integration outcomes are not as well-reasoned and analysed in a comparative perspective. With the notable exception of a few studies originated by the European Union (EU), almost no scholars have applied comparative statistical analysis across Europe, in order to identify any countries that might have more remarkable outcomes as regards the integration of immigrants. Overall, immigrants in receiving countries (and especially immigrants with citizenship of a non-EU member state) $)^{9}$ tend to be in a less favourable position than national citizens. Remarkably large gaps or disparities between the two groups (in domains such as the risk of poverty, social exclusion or income levels) are an extremely common outcome in almost all European countries. However, it remains important to determine just how wide these gaps are, and how much they differ by country and temporally.

This paper therefore addresses the following research questions:

Are third-country nationals (TCNs) exposed to significantly greater risk of poverty or social exclusion than national citizens across EU member states? Do TCNs and national citizens constitute two distinct social groups in most countries and particularly in countries with immigrant populations of similar composition (e.g. nationality)?

Are the living conditions of immigrants better in countries with well-developed integration policies, welfare settings and a greater emphasis on universalism and redistribution? In other words, does welfare generosity better protect immigrants (TCNs) against the risk of poverty or social exclusion?

Answers to these questions were investigated through comparative analysis using EU and Eurostat statistics ${ }^{10}$ - and definitions of integration (in the 'Zaragoza indicators'), as well as those from the OECD and MIPEX. Our basic thesis is that poverty is too diverse and complicated a phenomenon to be explained adequately by reference to a unidimensional model or simple monetary measure. 'All actors should recognise that migration and integration are complex processes that require careful and multi-faceted policy interventions' (Ruhs, Tamas \& Palme, 2019, p.251). The paper focuses on cross-national variation ${ }^{11}$ regarding the extent to which immigrants are more frequently at risk of poverty or social exclusion than nationals. It also aims to find patterns and possible explanations.

Relevant analysis pursued has been more or less exploratory and descriptive in nature, but results obtained may still make a substantive contribution to ongoing debate and research on the development and use of integration/social inclusion indicators, and on the way in which these link up with integration policies or welfare systems. At a secondary level, an empirical challenge is to test the significance of outcome indicators correlated with integration policies using the MIPEX index, given the limited and narrow nature of empirical efforts in this area. ${ }^{12}$

\footnotetext{
${ }^{9}$ In this paper, following the terminology used by Eurostat (2017) and Recchi (2016) among others, we distinguish between two categories of immigrant (foreign citizen), recognising: a) those from other EU-countries (or non-national EU citizens/ second-country immigrants) and b) those from a non-EU country or non-EU-citizens (i.e. third-country nationals - TCNs).

${ }^{10}$ Mainly from the EU-SILC (Statistics on Income and Living Conditions).

${ }^{11}$ Across EU member states, but also including the UK (plus Norway and Switzerland).

12 Bilgili, Huddelston and Joki (2015) for example test and link societal outcomes/indicators (e.g. employment rates
} 
The remainder of this paper involves a discussion of the poverty/social inclusion immigrant integration nexus (also in relation to the European framework of the 'Zaragoza indicators'), along with a description of social inclusion by reference to indicators (relative poverty or social exclusion), and the presentation of the main results of analysis, including differences across European societies. It continues by examining as to whether any differences noted depend on differences in integration policy as measured by the MIPEX index (with it being shown that this is barely the case). Finally, the paper concludes with a discussion of main findings.

\section{The immigration/social inclusion policy nexus: brief methodological considerations and empirical strategy}

Where integration is concerned, academic debate, research findings and policymaking integration have all developed without a common and accurate definition of progress, and still in the absence of an understandable vision as to the end result European policymaking ought to achieve. At a very simplistic level, 'integration' is taken mainly to relate to immigrants' participation in, and incorporation into, the receiving society (Grzymala-Kazlowska \& Phillimore, 2017, p.9; Gilmartin \& Dagg, 2018, p.5). It has also been defined as 'the process by which immigrants become accepted into society' (Penninx \& Garcés-Mascareñas, 2016; Penninx, 2019). For their part, Oliver and Gidley $(2015$, p.1) see the term as referring to ways in which migrants and a receiving society live together with immigrant interactions seen to involve both individuals and institutions.

The loose contention featuring in various research papers (e.g. Martiniello, 2006; Klarenbeek, 2019 ) is that integration does not depend solely on the commitments, efforts and achievements of immigrants themselves, being also a matter of the structure and openness of host communities. Integration is thus a two-way process.

Likewise, the definition from the International Organisation for Migration (IOM, 2012) recognises immigrant integration as a process of mutual adaptation between the host society and migrants themselves, both individually and as groups. For its part, the EU uses its 2004 Common Basic Principles on Immigrant Integration Policy to again define integration as a dynamic two-way process of mutual accommodation by all immigrants and residents of member states (EC, 2004).

While views on integration thus seek to emphasise a two-way process, most attention has actually focused on immigrant adjustment, and the ways in which relevant policy outcomes might be understood or measured. As a result, analyses of integration have been largely driven empirically and operationally, with a particular focus on narrow determinants and outcomes (Zetter et al., 2006; Phillimore, 2012; Grzymala-Kazlowska \& Phillimore, 2017). These may include the degree of immigrant inclusion and incorporation into the receiving society, or assessment of disparities when it comes the experiences of immigrants on the one hand and national citizens on the other (Recchi, 2016; Gilmartin \& Dagg, 2018).

In this paper, the study of immigrant integration first gains via exploration of a qualitative nature without emphasizing measurement of clear policy outcomes (i.e. the efforts or perceived capacity of a receiving society to incorporate immigrants). ${ }^{13}$ This involves the practical case of MIPEX (Huddleston, Bilgili, Joki \& Vankova, 2015; Hagelund \& Kavli, 2017, p.385; Scipioni \& Urso, 2017;),

among immigrants) with integration policies (e.g. MIPEX index), also identifying potential and actual policy beneficiaries/ vulnerable groups. However, their analysis does not relate to social inclusion.

${ }^{13}$ The distinction here is between the outputs and outcomes of policy, with the former taken to refer to specific measures (e.g. adoption of a law) and the latter to the impact such measures (e.g. the said law) might have had methodologically, MIPEX limits its scope to outputs. 
deemed the most-established indicator on integration, comparing policies ${ }^{14}$ and public laws in a series of countries, including all EU member states in the period 2007-2014. However, this is recognised as nothing more than a measure of integration policies, rather than their implementation or their impact/results. As no outcome indicators are included, there is no information on the actual integration or inclusion/exclusion of risk groups (Huddleston, Niessen, Ni Chaoimh \& White, 2011, p.7; Wiesbrock 2013). Another feature is the index's non-emphasis on inequality, with the focus being on the fight against discrimination as a more cohesive strategy for welfare policy. Research papers usually incorporate overall MIPEX scores (or scores for interesting specific policy areas) into their analysis, treating them as independent variables by which to compare policies, outcomes and other key issues relating to immigration. ${ }^{15}$

The use of the 'Zaragoza indicators' as a reference framework ensures a specifically 'focusing-in' on outcomes regarding the social inclusion of immigrants relative to national citizens. ${ }^{16}$ This specific set of proposed indicators refers, not only to income, but also to the risk of poverty or social exclusion. This is then a composite indicator taking account of the three components as follows:

- relative poverty (at-risk of poverty), when income is less than $60 \%$ of the national median equivalised disposable income; ${ }^{17}$

- severe material deprivation - i.e. the perforce presence of four or more of the 9 deprivations (i.e. inability to: pay rent or utility bills; keep home adequately warm; face unexpected expenses; eat meat, fish or a protein equivalent every second day; take a week's holiday away from home; have a car; have a washing machine; have a colour TV or have a telephone);

- labour-market exclusion, entailing life in a household in which the adults achieve less than $20 \%$ of their potential for work.

For this paper, preparatory work went beyond the risk of poverty or social exclusion, to include a focus on the new material and social deprivation indicator, but also on child poverty/deprivation and in-work poverty, as concepts explained below. ${ }^{18}$

The 'material and social deprivation' indicator was endorsed by the EU recently (Guio, Gordon, Najera \& Pomati, 2017), and extends to items relating to social activities. ${ }^{19}$ It thus takes account of: a) the inability for a household to: face unexpected expenses; afford a one-week annual holiday away from home; avoid arrears (in mortgage or rent, utility bills or purchase instalments); afford a meal with meat, chicken or fish every second day; afford to keep the home adequately warm;

\footnotetext{
${ }^{14}$ It comprises 8 policy areas (labour-market mobility, education, long-term residence, access to nationality, family reunion, political participation, anti-discrimination and health).

${ }^{15}$ For example, Recchi (2016) correlates the MIPEX index with the gap between third-country nationals and national citizens (the citizenship gap) when it comes to the risk of poverty or deprivation, using data from the EU-SILC. Bergh (2014) also uses MIPEX as an explanatory variable seeking to account for (OECD) cross-country differences in labour market gaps between immigrants and natives.

${ }^{16}$ Immigrant integration is understood as the extent of the inequality or gaps (divergence/disparity) between immigrants and non-immigrants - as evident in a range of outcomes relating to social inclusion (Huddleston, Niessen \& Tjaden, 2013; Recchi, 2016, p.182).

${ }^{17}$ Household income is 'equivalised' where 1.0 is assigned to the first adult; 0.5 to the second and each subsequent person aged 14 and over; and 0.3 to each child aged under 14 (OECD modified scale). Thus, low income, adjusted for household size and composition, is measured with reference to the 'average' person in society.

${ }_{18}$ We do not examine indicators such as self-reported health status, property ownership, or other new proposed indicators (self-reported unmet need for medical care, life expectancy, healthy-life years, housing-cost overburden, overcrowding or persistent poverty) - for which data are not available every year (ad hoc basis) or are associated implicitly with the risk of poverty or social exclusion. Besides, both Eurostat and the OECD provide detailed descriptive analysis for each integration policy. See for example OECD/EU (2018) and Eurostat (2019).

${ }^{19}$ The new indicator of material and social deprivation replaces the standard material deprivation indicator adopted by the EU in 2009.
} 
have access to a car/van for personal use; and replace worn-out furniture; as well as b) the inability for a person to: replace worn-out clothes; have two pairs of properly-fitting shoes; spend a small amount of money each week on him/herself; have regular leisure activities; get together with friends/family for a drink/meal at least monthly; and have an Internet connection. The deprivation rate is defined as the proportion of people in the whole population lacking at least five of these 13 items. Through methodological manipulations, this indicator (compiled for persons aged 16 or over) could also apply to children under 16.

Immigrants are expected to experience a significant degree of social and material deprivation, confirming much of the literature examining their social inclusion or exclusion in Europe.

As regards child poverty, our aim has been to examine inequalities among children with an immigrant or non-immigrant background, and - if poverty affects children to a greater extent than the population as a whole - to also examine cross-country variations (Michailakis \& Reich, 2009). In this perspective, reference to the conventional EU measure sees child poverty usually considered a lack of well-being, and defined in terms of a relative 'poverty threshold'. Thus, a child is perceived to be 'at risk of poverty' if he/she lives in a household or with parents who are below the 'poverty threshold'. However, this indirect measure of poverty is not child-specific, and reveals nothing about children's own experiences of poverty. Direct measures of children's individual living standards can instead identify, not simply how many children are poor, but also how poverty affects children. Nevertheless, in March 2018 a new specific child-focused deprivation indicator was agreed at the EU level (Guio et al., 2017; Kaczmarek-Firth \& Dupré, 2018). The child deprivation rate is the percentage of children aged between 1 and 15 years who suffer perforce from a lack of items from a series of selected deprivation indices. ${ }^{20}$

Although the data concerning child poverty and deprivation are not fully enough available to allow for a comprehensive comparison on the basis of nationals compared to TCNs ${ }^{21}$, it is our deliberate aim to examine child poverty. There is evidence that children suffer disproportionately compared with the population as a whole in many countries, and they are notably the ones affected most by the recent crisis (e.g. in southern Europe). It is possible that the presence of children with an immigrant background further worsens the picture and reality of living conditions for children in general. An interesting research question to be examined is then whether children, specifically those with an immigrant background, are significantly less likely to be poor in countries with more-generous safety nets.

Moreover, in-work poverty is also proposed as a new 'Zaragoza indicator'. We deliberately chose to emphasise this indicator as, according to Eurofound (2017) and Balourdos and Petraki (2019), joblessness is a major cause of childhood poverty/deprivation. The crisis seems to have hit immigrants severely as the sectors in which they found employment (e.g. construction, retail, food market) are affected most (Tilly, 2011, p.679). This is inter alia associated with the working-poor (Findlay, Geddes \& McCollum, 2010; Favell \& Recchi, 2011, p.65; Kasimis \& Papadopoulos, 2012; Fromentin, Damette \& Zou, 2017; SPC, 2018, p.6).

\footnotetext{
${ }^{20}$ The final list of items proposed by Guio, Gordon, Marlier, Najera and Pomati (2018) consists of 12 'children' and 5 'household' items, which cover both material and social aspects of deprivation. Children (aged 1-15) will be classified as deprived if they lack (for reasons of affordability) at least three items from the newly-recommended 17-item indicator. For the full list of indices see Eurofound (2017), Guio et al. (2018) and Guio, Marlier, Vandenbroucke and Verbunt (2020).

${ }^{21}$ According to the available data, children with an immigrant background are consistently at greater risk of poverty than those whose parents are not immigrants (TARKI, 2011). In 2016, the 'at risk of poverty' or social exclusion rate across the EU 28 for children with at least one parent who was a foreign citizen was almost twice as high (35.8\%) as that for children whose parents were nationals (18.8\%). Latest Eurostat data (for 2018) also find that, in the EU 27 , poverty among children at least one parent of whom was a foreign citizen was more than twice as severe as in children whose parents were nationals.
} 
Furthermore, political views have changed, with governments in receiving countries starting to pursue more-selective immigration policies. ${ }^{22}$ At the same time, immigrants' access to social protection-welfare benefits is influenced by attitudes towards more restrictive policies. As Geddes (2003) has argued, welfare states have become an internal method for the regulation of migration. By providing access to, or exclusion from, welfare support, European states have sought to welcome some forms of immigration, while preventing or discouraging others. Research results also show that the latest global economic crisis was among the factors that gave rise to more-restrictive policies regarding labour migration (Tilly, 2011). Generous welfare states that receive a great deal of unwanted immigration ${ }^{23}$ thus control access to social rights, which leads to large poverty gaps between immigrants and nationals (Hooijer \& Picot, 2015). One open question is that posed by Ette and Faist (2007, p.9): Do national immigration policies develop towards a similar shared model or does the Europeanisation of national policies lead to greater divergence?

This particular perspective necessitates a focus on social protection, as it is obvious that, arithmetically, for any given pre-transfer rate of poverty risk, the social-protection expenditure to be expected depends on the effectiveness of the targeting to reduce the post-transfer rate of poverty risk (Marlier, Atkinson, Cantillon \& Nolan, 2007, p.86). Empirical research of recent decades actually finds a strong inverse correlation between poverty and social transfers, meaning that countries with a higher level of social expenditure are likely to have lower poverty rates (Förster \& Mira D'Ercole, 2005; Caminada \& Goudswaard, 2009; Anderson, d'Orey, Duvendack \& Espositoa, 2018). However, the impact of government spending ${ }^{24}$ on poverty may vary among member states, e.g. in line with the sector, effectiveness of targeting and means of financing (Miežienė \& Krutulienè, 2019).

In this paper we use social-expenditure data ${ }^{25}$ to examine the extent or generosity of European welfare states. The argument holds that differences in spending levels between countries may be examined, and evaluated for their effect on immigrant poverty. Accordingly, the indicator has been applied to various theories of welfare-state change, whereby economic growth, rising social needs and modernisation processes are supposed to affect the welfare provision of affluent democracies, probably negatively (Otto, 2018).

This point of view requires a more specific, operationalised and testable version of the original research question, asking whether a member state that could be described by a high MIPEX score and presumably with well-developed immigrant integration/social inclusion policies and a more generous welfare system associated with high social expenditure, also presents relatively limited risk of poverty or social exclusion among TCNs. ${ }^{26}$

\footnotetext{
${ }^{22}$ The politicisation of migration could gain partial illustration via rising anti-migrant sentiments expressed through political movements across Europe, e.g. Golden Dawn in Greece, the PEGIDA movement in Germany, the UK Independence Party, and the National Front in France (Papadopoulos, 2016, January 8).

${ }^{23}$ Mainly humanitarian and family immigrants lacking access to the labour market and the welfare system. For the past twenty years, family reunification has actually been one of the main reasons for immigration into the EU. There is an entry channel allowing those already residing legally in a member state to be joined by family members.

${ }^{24}$ Expressed, for example, as social expenditure as a percentage of gross domestic product (GDP) (Caminada \& Goudswaard, 2009).

${ }^{25}$ While several measures have been considered in the literature, we use social expenditure as a percentage of GDP, as this is thought to capture the extent of the resources a government devotes to social protection while still representing a measure of a fairly highly degree of comparability across countries and over time.

${ }^{26}$ In generous welfare states an immigrant will be granted greater access to benefits for material, institutional or cultural reasons. In contrast, due to fiscal pressures and welfare restrictions, generous welfare states are more likely to exclude immigrants from access to benefits (under the dualisation hypothesis) (Römer, 2017).
} 


\section{Measuring the social inclusion of immigrants in Europe: empiri- cal results}

This section first describes the situation of immigrants/ TCNs relative to national citizens using the indicators described previously. The particular focus is on the risk of poverty or social exclusion, with the aim being to identify country-to-country variations, patterns or classifications of possible integration types. Moreover, we test the relationship between indicators of social inclusion and levels of immigrant policies (as measured by the MIPEX index), with a view to determining if these policies do target reduction of the gap between nationals and non-nationals consistently, or rather install institutional barriers and segregation leading to lower immigrant incomes and worse living conditions (Hooijer \& Picot, 2015; Waters \& Pineau, 2015). The empirical analysis also tests the relationship between the risk of poverty for nationals and TCNs on the one hand, and on the other MIPEX, the level of social expenditure and other ad-hoc specified variables, such as unemployment rate and GDP per capita. To identify patterns, the data are examined in three ways. First, a preliminary analysis is carried out by looking at pairwise correlations between variables of interest. Second, baseline results are obtained by running standard linear ordinary least-square regressions based on models specified from existing literature. Third, use is made of modified regression models including proposed new ad-hoc explanatory variables.

\section{Linking policy and social-inclusion outcomes: Poverty or social exclusion in relation to MIPEX}

An analysis of the composite variable of 'at risk of poverty or social exclusion' across the EU member states reveals that TCNs were generally characterised by a higher share than national citizens in 2018 (and in 2015); ;7 Poland was the only exception among the 28 member states for which data are available, ${ }^{28}$ in which a slightly higher share of national citizens were at risk of poverty or social exclusion compared with TCNs (19.4 vs. 16.7\%). In 2018, citizens of non-EU nationality in Sweden were 4 times as likely as nationals to be at risk of poverty or social exclusion, while the respective percentage was 3.5 times as high in France, 3 times as high in Belgium, 2.6 times as high in The Netherlands, 2.8 times as high in Austria, 2.6 times as high in Denmark, and considerably lower in the other countries (Fig. 1 and 2). ${ }^{29}$ Although the proportion of persons at risk of poverty or social exclusion in the EU has been decreasing since 2015 (for both nationals and TCNs), it remains some distance from the Europe 2020 target. ${ }^{30}$ However, a pattern that emerges is for observed risk rates for immigrants to be high, for example in 2015, in Greece, Spain, Belgium, Sweden and Italy, i.e. countries with different macroeconomics, past migration history, integration principles, and welfare systems and generosity. ${ }^{31}$

With regard to the indicators contributing to the risk of poverty or social exclusion (Fig. 2), our examination of difference between nationals and TCNs revealed that, for most cases the trend is

\footnotetext{
${ }^{27}$ The data refer to citizens aged 18 and over.

${ }^{20}$ We present data according to availability for the 28 member states. In selected cases, we also include Norway and Switzerland to minimise the small-sample problem.

${ }^{29}$ Typically, no data are available for Romania and Slovakia.

${ }^{30}$ Lifting at least 20 million people out of the risk of poverty and social exclusion compared to the baseline. A reduction in numbers of people at risk of poverty or social exclusion in the EU constitutes a key target of the Europe 2020 strategy.

${ }^{31}$ Switzerland presents relatively low rates for immigrants, though still almost double in comparison with nationals, while the respective rate for Norway is close to those describing Denmark or Finland.
} 


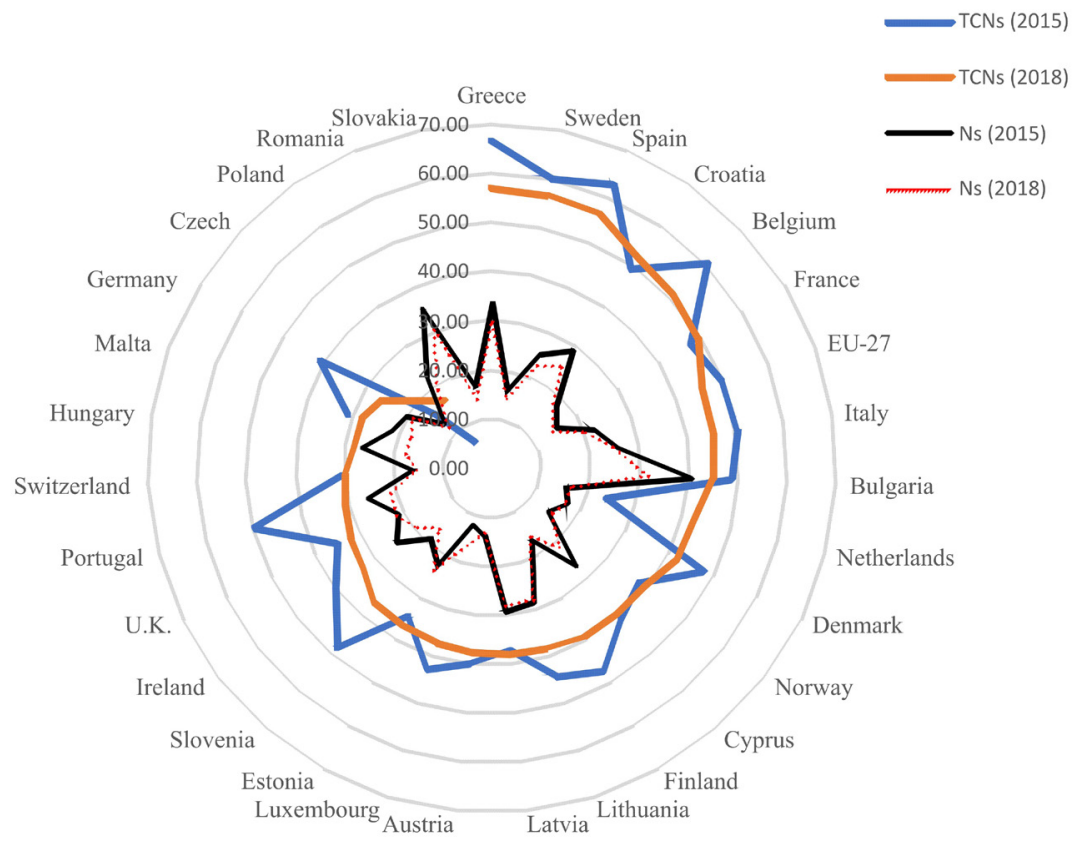

Figure 1. 'At risk of poverty or social exclusion' in the EU member states, Norway and Switzerland, by nationality (NCs vs. nationals - Ns), in 2015 and 2018

Source: authors' computations based on the Eurostat online database.

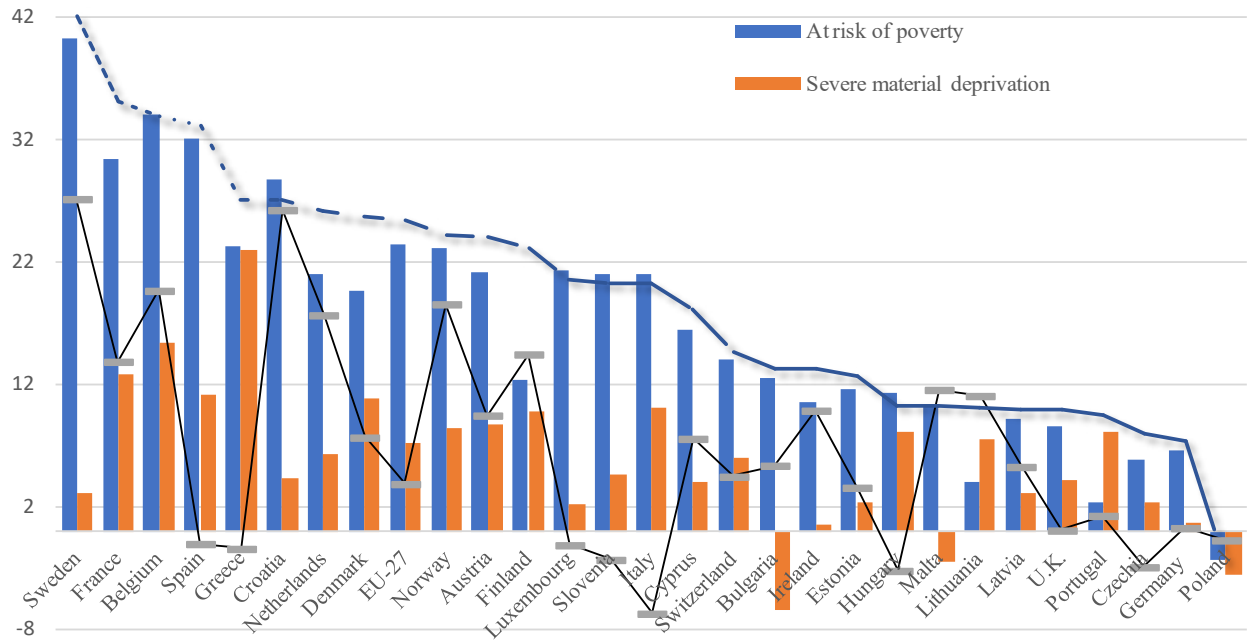

Figure 2. 2018 differences (D) in the risk of social exclusion and of poverty, as well as severe material deprivation rate and intensity of work among TCNs vs. National (Ns) in the cases of EU member states, Norway and Switzerland

Source: authors' computations from Eurostat's online database. 
similar to that of the EU 27. Differences involving the risk of poverty are very much greater than those involving the remaining indicators. In 2018, TCNs in Spain were 5 times as likely as nationals to be at risk of poverty, while the corresponding figures were more than 3 times as high in Bulgaria, Slovenia, The Netherlands, Italy, Sweden and Norway.

Where the severe material deprivation rate is concerned, we note that the largest differences between TCNs and nationals (of over 10 percentage points) are observed in Greece (+23\%), Belgium $(+15.4 \%)$, France $(+12.8 \%)$, Spain $(+11.1 \%)$ Denmark $(+10.9 \%)$ and Italy $(+10.1 \%)$. We also find that Sweden, Belgium, Norway, The Netherlands, Finland and France feature the most-marked differences for the 'very low work intensity' indicator.

Examining the patterns of variation of MIPEX for 2015 in combination with the various levels for at risk of poverty or social exclusion for the same or coming years ${ }^{32}$ among European countries is a matter of crucial importance for the grouping and clustering of countries (or regimes) in line with their similarities (or differences). It was expected that too-scoring countries for MIPEX would apply an integrated immigrant policy in all aspects of society; i.e. politics, education, labour-market mobility, etc. However, evidence included in Figures 3 and 4 leads to contradictory results as regards social inclusion. First, countries with high MIPEX scores, like Sweden, ${ }^{33}$ Belgium, Spain, The Netherlands, or Denmark, leave TCNs almost 'unprotected' from the risk of poverty or social exclusion, but protect nationals rather well; ${ }^{34}$ as is indicated by the relatively low observed risk rates (Fig. 3 and 4). It seems that in these countries the common presence of immigrants or even refugees appears to ensure greater restrictiveness in allowing social protection. ${ }^{35}$

Second, the differences (D) in rates of at risk of poverty or social exclusion (between nationals and TCNs) across the MIPEX overall scores (mainly referring to absolute - between-rates - differences) produce no clear clustering between European countries. The highest values characterise Sweden, The Netherlands, Belgium, Denmark or even France, with a high MIPEX index. This group could also extend to Greece or Croatia, but this is precluded on account of their lower MIPEX scores (Fig. 3). In 2018, the only exception was Poland, where the share of TCNs (16.7 \%) in conditions of poverty or social exclusion were slightly lower than the share of nationals (19.7\%).

Third, a cluster of European countries is included in the left lower quadrant where the at risk of poverty or social exclusion difference (D) is low (as is the case for the countries in the left upper quadrant), and fluctuates below the EU mean. The countries involved (Slovenia, Switzerland, Czechia, Cyprus, Bulgaria, Latvia, Lithuania, Malta and Hungary) are very diverse in economic and social terms (including composition of the immigrant community), making it difficult to point to similarities or a clear pattern (Fig. 3).

\footnotetext{
32 Recchi (2016) correlates MIPEX for 2007 with the risk of poverty or material deprivation for 2012, assuming that integration policies only exert their full impact after a certain period of time.

${ }^{33}$ Sweden is actually an outlier, showing the highest MIPEX score and the most marked difference in poverty or social exclusion rates between TCNs and nationals.

${ }^{34}$ Only Spain now seems to be distancing itself from Scandinavian countries or Belgium and The Netherlands, to come closer to Italy or the UK.

${ }^{35}$ According to the latest Eurostat data, relative to the size of the resident population, Luxembourg (on $47.5 \%$ ) had the EU's highest rate of immigration in 2019. A high proportion of non-nationals ( $10 \%$ or more of the resident population) could also be observed in Cyprus, Malta, Belgium, Germany, Latvia, Estonia, Spain, Ireland and Austria, while in Greece that year the figure approached 7.8\%. Belgium, Ireland, Cyprus, Luxembourg, Malta, The Netherlands, Austria, Romania, Slovakia and the United Kingdom were EU member states in which non-nationals were mainly citizens of other member states. This means that in most EU member states, a majority of nonnationals are citizens of non-EU countries. In the EU, around two-thirds of immigrants are from non-EU countries. In the case of Latvia and Estonia, the proportion of citizens from non-member countries is particularly large due to the many recognised non-citizens (mainly former Soviet Union citizens, who are permanently residents in these countries but have not acquired any other citizenship) (Eurostat, 2020).
} 


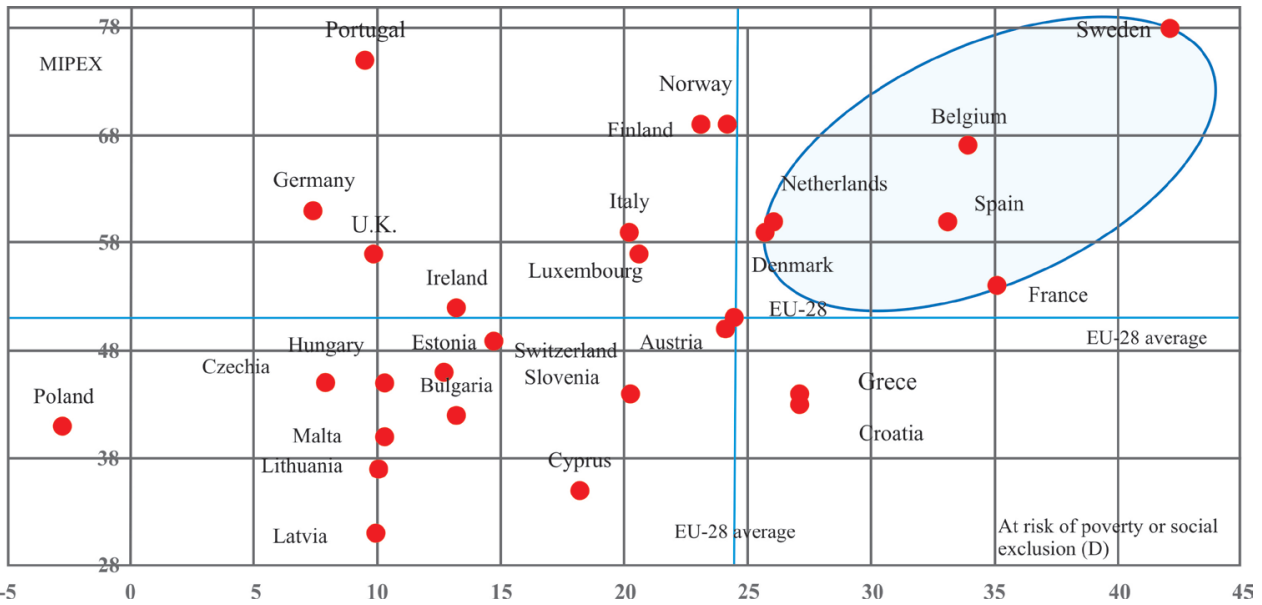

Figure 3. MIPEX (2015) and the risk of poverty or social exclusion difference (D) among nationals vs. TCNs (in 2018), in the cases of EU member states, Norway and Switzerland

Source: authors' computations using for MIPEX and in the Eurostat online database.

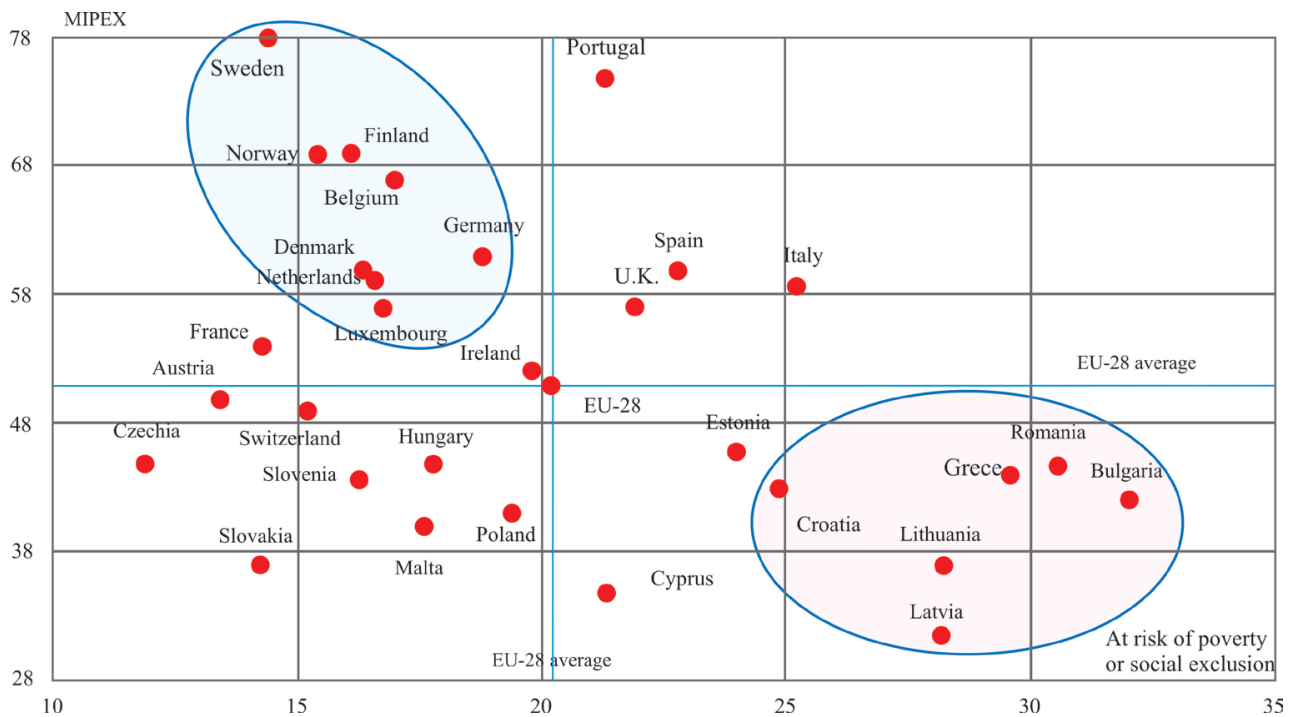

Figure 4. MIPEX (2015) and the risk of poverty or social exclusion for nationals only (2018), in the cases of EU member states, Norway and Switzerland

Source: authors' computations using data for MIPEX and in the Eurostat online database. 
Fourth and believably more significant, a clear polarisation is observed if MIPEX is examined in parallel with the risk of poverty or social exclusion of nationals alone. Countries at the top for MIPEX overall scoring (e.g. Sweden, Belgium, Finland, The Netherlands, Denmark, Germany, Luxemburg and France) show the lowest levels of poverty or social exclusion. On the other side (the right lower quadrant of Fig. 4), Greece is joined by Bulgaria and Romania, while also being close to Croatia, Lithuania, Latvia, Hungary and Cyprus.

These could probably be indications of an uneven 'integration/social inclusion turn' for the most prosperous countries of Europe; or a trend towards stricter selective immigration policies, something that should at this stage be considered an indication, and not as a causal relationship.

\section{Median income, monetary poverty, child poverty, material and social depriva- tion and in- work poverty}

In 2018, TCNs had a lower annual median equivalent disposable household income than national citizens in virtually every EU member state, as well as in Norway and Switzerland. The largest gap (absolute difference) in median income favouring national citizens was noted for Luxembourg (equal to 17,379 euros). In Sweden, Belgium, Austria, France, Denmark and The Netherlands, but also in Switzerland and Norway, the differences are in the wide range 7000-13,000 euros. ${ }^{36}$ In relative terms, the largest differences are observed in Sweden, Spain and Belgium (over $70 \%$ ). In Greece, France, Italy, Croatia and Luxembourg the median income of nationals was also more than $50 \%$ above that of TCNs (Fig. 5).

According to data for the same year, $15.5 \%$ of national citizens (aged 18 and over) living in the EU, were at risk of poverty. However, at $38.1 \%$, the risk of poverty was more than twice as high for TCNs living in Europe. And in terms of differences from one country to another, the share of TCNs at risk of poverty was usually higher than that of nationals facing a similar risk. Poland proved to be the only exception in 2018, recording a slightly lower share of foreign TCNs at risk of poverty. In contrast, in Sweden, foreign non-EU citizens were 4 times as likely as nationals to be at risk of poverty, while relatively large differences were also recorded in France, Slovenia, Austria, Belgium, Spain, Croatia and Cyprus. A downward trend in the share of persons at risk of poverty in the EU has been noted since 2015 (Fig. 6), and in general it is Czechia, Finland, Denmark and Sweden, The Netherlands and Luxemburg that record the lowest poverty rates for nationals. Citizens of Anglo-Saxon-type welfare states and countries in southern Europe present relatively higher poverty rates.

Countries with high median incomes and high levels of social protection or generous welfare states (e.g. Sweden and France) thus feature the highest income and 'at risk of poverty' differences, grouping them together with Spain, even though it has a totally different welfare regime. We also find a number of countries with adverse economic or social settings in a cluster, with low or moderate income and poverty differences.

When it comes to Sweden, for example, as a multicultural country, it may be that policies strengthen the welfare state, but it is now obvious that the overall generosity is primarily aimed at supporting the native population.

Moreover, and again in 2018, 8.4\% of the EU's country nationals (aged 18 and over) were deemed at risk of in-work poverty, while the share among foreign TCNs was higher, at $24.1 \%$. The highest risk of in-work poverty among TCNs was that recorded in Spain (36.8\%), while Bulgaria, Italy, Cyprus, Luxemburg and Greece all recorded shares within the range $26-33 \%$ (Fig. 7). For the

\footnotetext{
${ }^{36}$ The median income of foreign non-EU citizens living in Bulgaria and Poland was actually higher than the median income of nationals.
} 


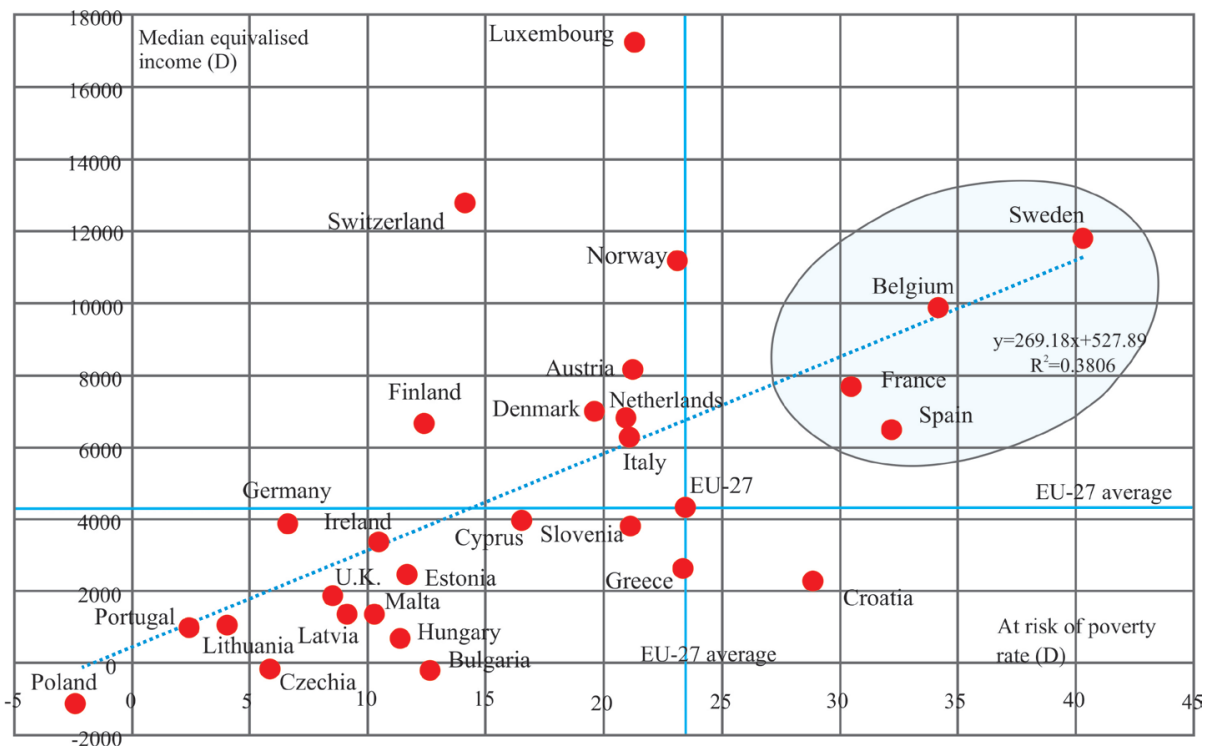

Figure 5. Median equivalised income and people aged 18+ years at risk of poverty. 2018 differences (D) by citizenship (nationals vs. TCNs) in the cases of EU member states, Norway and Switzerland Source: authors' computations using data in the Eurostat online database.

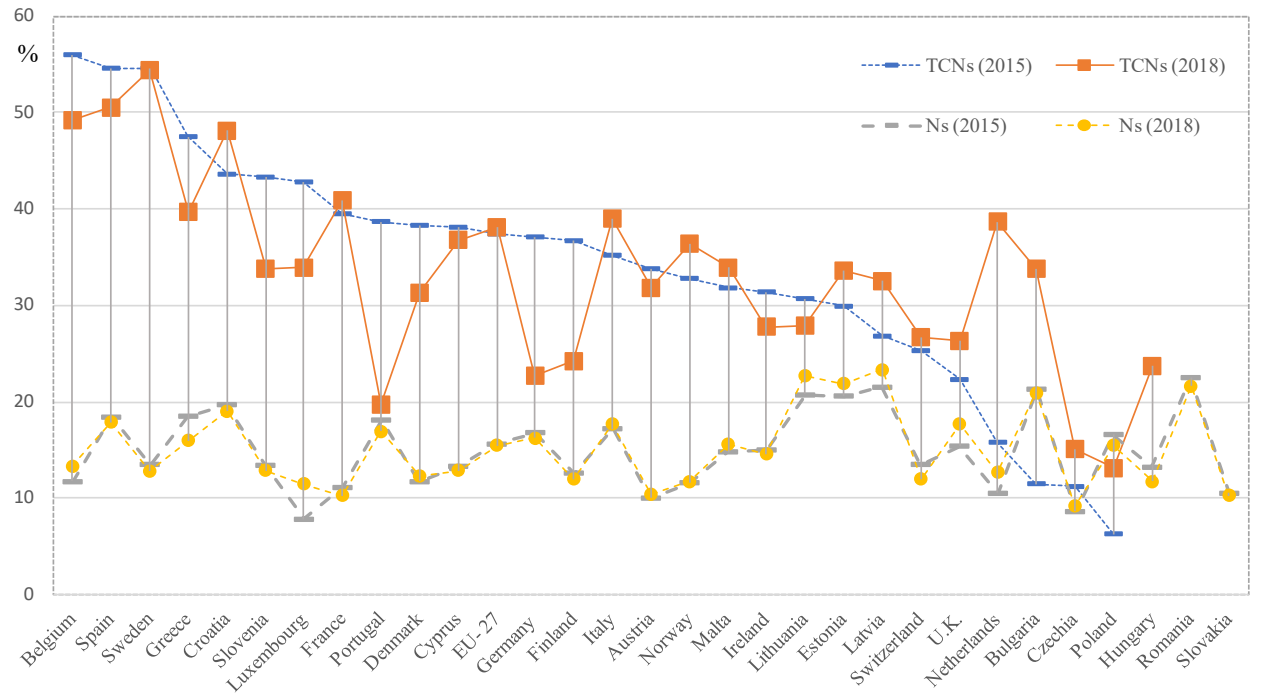

Figure 6. People aged 18+ at risk of poverty in 2015 and 2018, by citizenship (nationals - Ns vs. TCNs), in the cases of EU member states, Norway and Switzerland

Source: authors' computations using data in the Eurostat online database. 


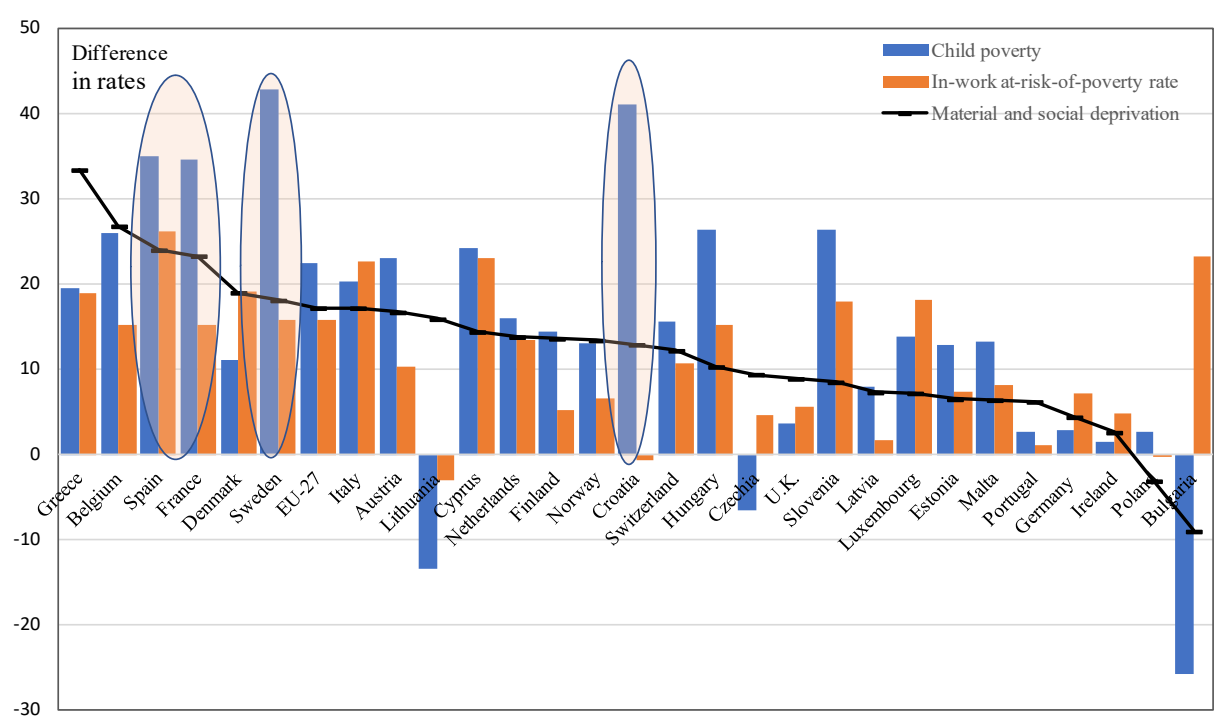

Figure 7. 2018 differences (D) in child poverty (among 0-17 years), and material and social deprivation rate and in-work poverty (among people aged 18+), where TCNs are compared with nationals - Ns in EU member states, Norway and Switzerland Source: authors' computations using data in the Eurostat online database.

same countries the differences between the two distinct groups of citizens exceed 18 percentage points (as it also did in Denmark). ${ }^{37}$

Following the pattern with previous results, in almost all member states children (aged 0-17) with a migratory background ${ }^{38}$ are also found to be more exposed to the risk of poverty. The highest rate of immigrant child poverty is the $59.6 \%$ recorded in Croatia, while more than half of all immigrant children are also at risk of poverty in Spain (56.0\%) and Sweden (54.0\%). The lowest risks of poverty facing children with at least one parent who is a foreign citizen characterise Lithuania and Czechia, with respective shares of $10.5 \%$ and $4.6 \%$. By contrast, in Sweden, immigrant children were 4.8 times as likely to be at risk of poverty as those whose parents are nationals. Relatively large differences of this kind were also recorded in Slovenia (3.8 times as likely), France (3.3 times), Croatia and Hungary (both 3.2 times; though low reliability for the latter data) and Cyprus (3.1 times as likely). The disparity between the two groups of children is also assessed as very marked in Croatia, Spain and France (over 34 percentage points). Besides, the correlation with the respective difference in the material deprivation rate is significant, as also shown in Fig. 7 (correlation coefficient +0.62).

Furthermore, Fig. 8 confirms how, in most of the countries studied, there is a lack of any linear correlation between the 2014 level of poverty facing children (0-17 year-olds) with an immigrant background and the child-specific material deprivation rate (total). ${ }^{39}$ The situation facing children is most severe in Greece, Spain, Lithuania and Italy, where both rates are extremely high. Clear

\footnotetext{
${ }^{37}$ Croatia and Lithuania were the only member states in which the risk of in-work poverty is greater for nationals than for foreign citizens.

${ }^{38}$ With at least one of the parents being a foreign citizen. Eurostat data do allow a distinction to be drawn for these children as compared with those with each parent being a national.

${ }^{39}$ The data for this indicator are available only for this year; and for children below 15 .
} 


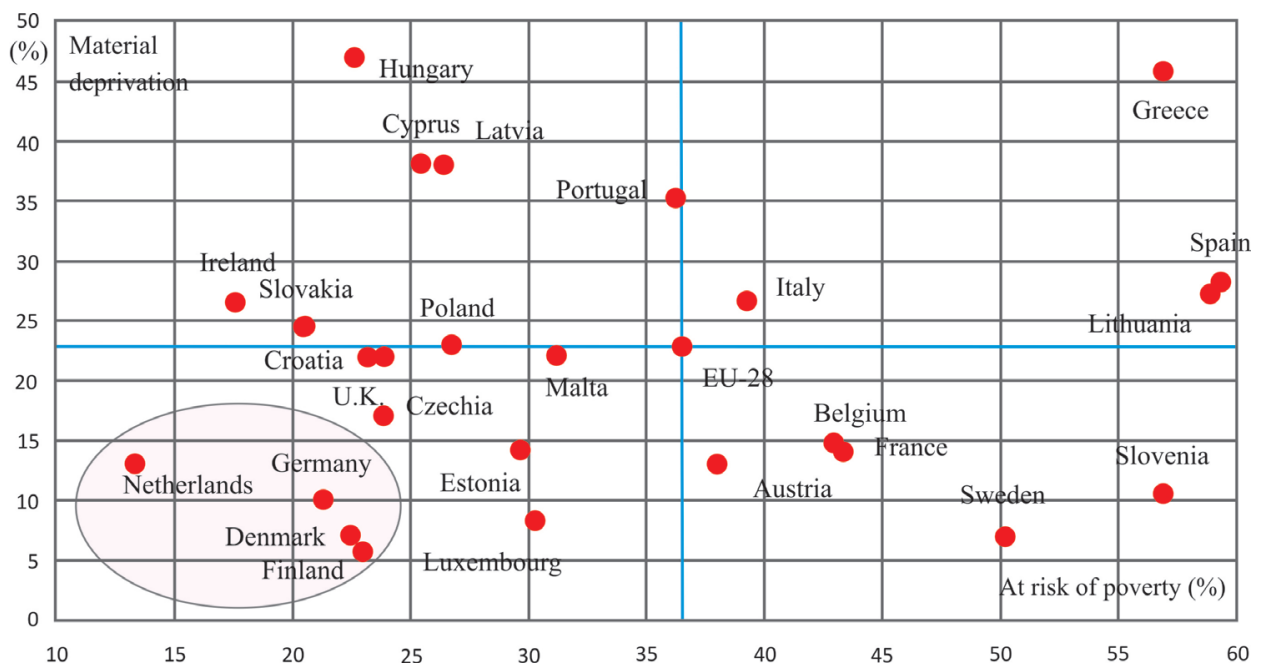

Figure 8. 'At risk of poverty' rate for children (0-17 years) with immigrant background by child-specific material deprivation rate* across EU member states, 2014

*Material deprivation data is available only for year 2014 and for all children (1-14 years).

Source: authors' computations using data in the Eurostat online database.

indications of better performances as regards both rates were to be observed in more-prosperous countries, including Denmark, Finland, Germany and The Netherlands, though lower material deprivation rates are dominant in these countries. In turn, we believe that the situation of immigrant children both of whose parents are from a non-EU country is in some sense hidden from analysis by data restrictions. There is empirical evidence that the crisis period saw child poverty and material deprivation worsen more rapidly in the case of children than the population as a whole in many countries (Chzhen 2014; Chzhen, Bruckauf \& Toczydlowska, 2017). So, to augment the newly-developed child-specific material deprivation indicator, further robust and reliable data are needed to allow for a further-reaching investigation of the living conditions experienced by immigrant children.

\section{Testing the linkage between social protection and poverty}

As noted previously, there is a strong inverse relationship between poverty rates and the level of social expenditure - a finding now well-established in empirical studies (Caminada, Goudswaard \& Koster, 2012). Countries with a higher level of welfare expenditure are likely to have lower poverty rates. Data in Figure 9 confirm such a strong and significant correlation between expenditure (as a percentage of GDP in 2017) and poverty rates among countries' nationals. Equally, there is no significant correlation where the 'at risk of poverty' rate for TCNs is considered.

We performed a cross-country regression analysis for social expenditure and poverty rates (not explaining/determining poverty levels), also following Caminada et al. (2012) in also accounting for the possibility of poverty being influenced by ageing-society differences (expressed in terms 


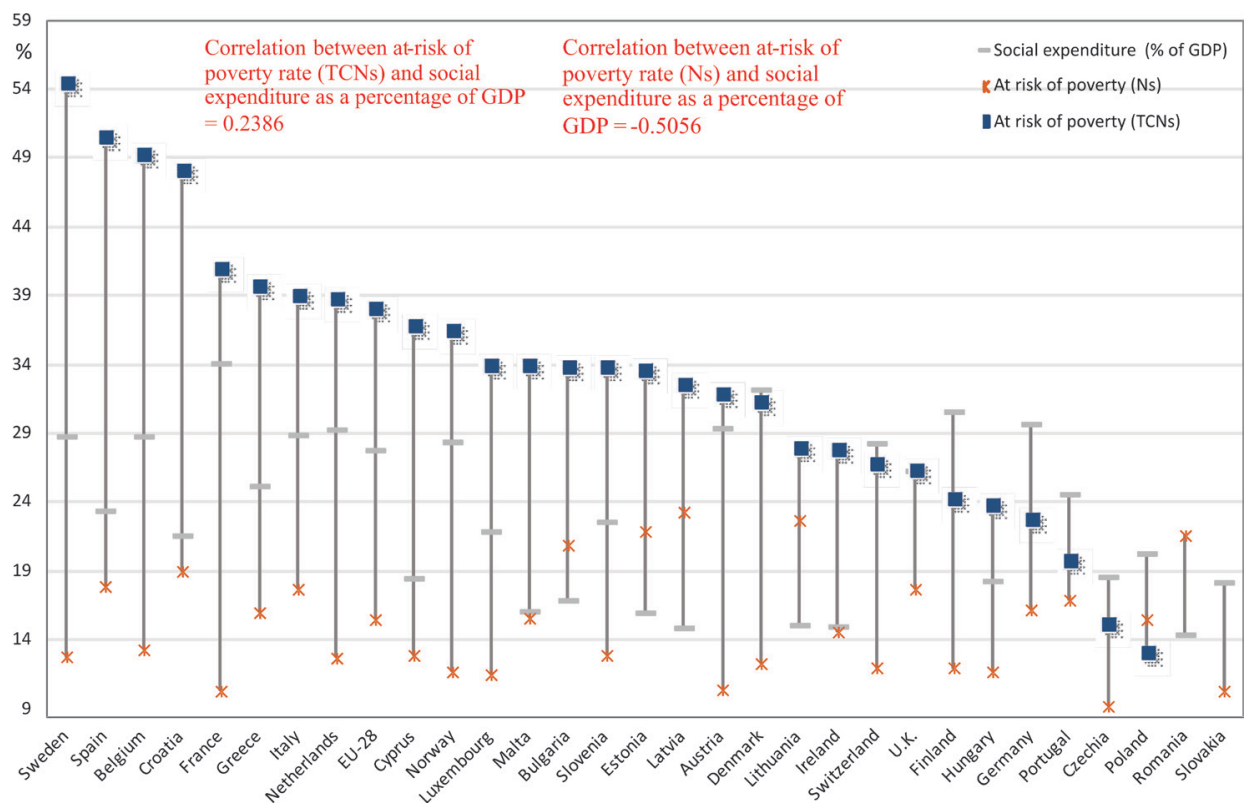

Figure 9. 2017 Social expenditure (as a \% of GDP) and at risk of poverty rate by nationality (nationals - Ns vs.

TCNs) in EU member states, Norway and Switzerland

Source: authors' computations using data from the Eurostat online database.

of the old-age dependency ratio), ${ }^{40}$ unemployment rate (among $15-65$ year-olds) ${ }^{41}$ and economic growth (GDP per capita in euros), ${ }^{42}$ given the way in which these factors may represent different constraints on income-transfer systems. ${ }^{43}$ Explicitly, we use a modified framework by applying multiple regressions (in cross-country analysis), focusing primarily on the relationship between poverty rates among TCNs versus nationals, and social expenditure.

In assessing the significance of the coefficients estimated for 2017, we confine ourselves to simple regression analysis (with the approach taken to estimating coefficients based on a linear ordinary least-square - OLS regression model). The results are as presented in Table 1.

Quite a strong inverse relationship is indeed to be noted between the level of social expenditure in EU 28 member states plus Norway and Switzerland and national citizens' levels of poverty, with account also taken of the old-age dependency ratio (affected positively). Remaining variables (and more precisely unemployment and GDP per capita) appear not to be significant statistically,

${ }^{40}$ Ageing is a serious problem for all member states, which influences their pension systems. In that context, we view old-age dependency ratio as a better index than, e.g. the percentage of persons 65 years and over in the overall population; as it actually measures the numbers above 65 years (defined as being in old age) in relation to those aged between 15 and 64 (defined as of working age). In other words, this ratio tells us how many retired people a potential worker has to sustain. It should be noted that this variable covariates with others and should not therefore be included in empirical specifications - as the elderly receive a disproportionate share of the largest social-expenditure categories, pensions and healthcare. However, Caminada et al. (2012) explain that there are spillover effects into the other covariates and into social spending. This justifies inclusion in the regression analysis.

${ }^{41}$ This indicator is also one of the key 'Zaragoza indicators' (integration into the labour market).

${ }^{42}$ As a proxy for rich countries. Note that we do not use the PPS per capita invoked by Caminada et al. (2012).

${ }^{43}$ We only focus on the impact of social transfers on income poverty, having in mind that, in fact, several EU member states put increasing emphasis on active inclusion strategies by which to facilitate labour-force participation among lower-income groups (EC, 2008, p.101; Caminada et al., 2012). This may also be an effective strategy when it comes to tackling poverty. 
Table 1. Regression analysis for 2017 EU poverty rates and social expenditure, with account also taken of other control variables

\begin{tabular}{|l|c|c|c|c|}
\hline & $\begin{array}{c}\text { Dependent variable: } \\
\text { 'at risk of poverty' rate } \\
\text { for nationals - Ns }\end{array}$ & $\begin{array}{c}\text { P-value } \\
\text { (sig) }\end{array}$ & $\begin{array}{c}\text { Dependent variable: } \\
\text { 'at risk of poverty' } \\
\text { rate for TCNs }\end{array}$ & $\begin{array}{c}\text { P-value } \\
\text { (sig) }\end{array}$ \\
\hline Social expenditure (\% of GDP) & -0.577 & 0.000000 & 0.190 & 0.679 \\
\hline Old-age dependency ratio & 0.746 & 0.002 & 0.329 & 0.681 \\
\hline Unemployment rate & 0.114 & 0.475 & 1.337 & 0.012 \\
\hline GDP per capita (Euros) & 0.00004313 & 0.340 & 0.0000001 & 0.470 \\
\hline Intercept & 4.853 & 0.376 & 5.792 & 0.776 \\
\hline$R^{2}$ & 0.577 & & 0.326 & \\
\hline Adjusted R $R^{2}$ & 0.510 & & 0.209 & \\
\hline F-statistic & 8.530 & & 2.783 & 0.051 \\
\hline No observations & 30 & & 28 & \\
\hline
\end{tabular}

Source: authors' computations based on data in the Eurostat online data base, using SPSS.

suggesting that these factors do not affect adults' (i.e. over-18s') risk of poverty in the European countries selected. It is the reference to social spending as a proxy for generosity that generates the most significant results, and with an adjusted $R^{2}=0.510$, the model explains $51 \%$ of the variance in poverty among nationals. There is also support for the hypothesis that a higher value for a country's old-age dependency ratio denotes greater pressure on the social security system, and hence an increased risk of poverty among nationals.

Entirely different results are obtained using the 'at risk of poverty' rate among TCNs, with only the unemployment rate significant (as more or less expected given immigrant poverty's strong dependence on labour-market prospects and the probability of securing a salaried position). The relation is of course positive as an unemployed immigrant is more or less a poor immigrant. Our results suggest that state income transfers may indeed prove an effective policy instrument when it comes to alleviating poverty; but only for some nationals, and not for immigrants of non-EU member state nationality. The evidence is thus consistent with an explanation that welfare-state generosity in many countries fails to correlate with lower rates of immigrant poverty. ${ }^{44}$

\section{Conclusions}

Integration of immigrants measured as social inclusion or low levels of poverty and social exclusion continues to show marked heterogeneity across Europe. In seeking to account for this, our descriptive results first note the different paths towards socioeconomic integration open to and taken by national citizens, as opposed to TCNs. These possible paths are indeed influenced by various characteristics of destination countries (notably their welfare systems, patterns of discrimination, and so on).

\footnotetext{
${ }^{44}$ We deliberately included the total MIPEX score as an explanatory variable in both equations addressed in Table 1. As the results showed no significance, they were removed from the final estimation. Overall analysis shows that integration policies, as ranked by the MIPEX classification, are not relevant in assessing existing differences in social inclusion among TCNs and nationals. Other types of country-level factors seem to affect the risk of immigrant poverty with respect to nationals.
} 
Immigrants are faced with a higher risk of remaining poor or socially excluded than nationals not only in southern Europe, but in fact in most European countries. The situation is most severe for TCNs, who tend to be over-represented in the lowest income decile, being subject to poverty or social-exclusion rates less favourable than among nationals, and only poorly integrated into host societies from an economic (i.e. income- or work-related and material-deprivation) perspective.

Perhaps obviously, there is no clear polarisation among EU countries or welfare states, with the 2018 values for the composite indicator of 'at risk of poverty or social exclusion' among TCNs being $57.1 \%$ in the case of Greece and $56.7 \%$ for Spain, as compared with highest-placed Sweden on $57.9 \%$.

Although TCNs may be attracted by the welfare generosity in countries like Sweden with a high level of equality, or even prosperous countries like Germany or The Netherlands, their living conditions in these countries are likely to be worse - and the risk of poverty very much higher - than among nationals.

A clear trend is for countries of the South European cluster (such as Greece or Spain) to face high rates of poverty or social exclusion, just as do certain Northern and Northwestern European countries (such as Sweden and Belgium). Generally, immigrants seem to represent a 'secondary' social group, excluded from social-welfare benefits even in generous welfare states - as is indicated by the high MIPEX scores, or the high level of social expenditure in connection with immigrant poverty or social exclusion.

Within those social democratic states classified as the most generous (and with high MIPEX scores), national citizens ('the insiders') enjoy a great deal of protection - as relatively lower rates of poverty or social exclusion make clear; while immigrants do not. Thus countries with generous welfare states, characterised by noticeably high levels of public spending, do not extend this generosity to immigrants.

Thus, in drawing on the available empirical evidence, we are compelled to reject the premise that immigrant integration/social inclusion is a two-way process. There was thus an enforced refocusing of the work reflected in this paper - in the direction of differences between nationals and foreigners where an acceptable way of life is concerned. It is a picture of a worse immigrant situation in terms of poverty or social exclusion that has therefore gained presentation.

It becomes evident that most countries' immigrant social-inclusion policies are not an extension of the social protection or welfare targeted at national citizens. Indeed, in a context of lower rates of poverty or social exclusion (as in Scandinavian countries), the gap between nationals and TCNs not only persists, but is in fact a wide one. Not paradoxically, this is also the situation in societies where welfare structures are traditionally fragmented and more fragile, with support therefore offered for the idea that specific immigrant policies are not effective.

There is now a need for further research and more analysis comparing immigration and integration in different countries. One particularly interesting area of research would seek to understand the interactions between economic and social integration, as well as the latter's different dimensions. Thus, for instance, is active inclusion sufficient to achieve immigrants' social integration? Or is this more or less a policy suitable for nationals?

Finally, as most studies to date have mainly analysed poverty and social exclusion or integration from the perspective of the adult immigrant, it remains important to further develop understanding on how the same policies influence immigrant children. This would basically be a new area of research, which demands not only a well-developed, child-focused deprivation indicator (or indicators) and policies targeted to favour immigrant children, but also robust and reliable databases. 


\section{References}

Anderson, E. M., d'Orey, A. J., Duvendack, M., \& Espositoa, L. (2018). Does government spending affect income poverty? A meta-regression analysis. World Development, 103, 60-71. https://doi. org/10.1016/j.worlddev.2017.10.006

Balourdos, D., \& Petraki, M. (2019). Understanding Family Demographic Processes \& In-Work Poverty. Paper presented at International Conference on 'Local Democratic Challenges: Environment, Inequalities and Resilient Cultural Mediation in Fragile/Transitional Communities'. Chania, Crete, Greece, 09-11 September.

Bergh, A. (2014). Explaining Cross-country Differences in Labor Market Gaps between Immigrants and Natives in the OECD. IFN Working Paper, 1036. Retrieved from http://papers.ssrn.com/sol3/papers. cfm?abstract_id $=2480517$

Bilgili, Ö., T. Huddelston, A., \& Joki, A. L. (2015). The Dynamics between integration policies and Outcomes: Synthesis of the Literature. Retrieved from http://www.migpolgroup.com/portfolio/the-dynamics-between-integration-policies-and- outcomes-a- synthesis-of-the-literature

Caminada, K., \& Goudswaard, K. (2009). Effectiveness of poverty reduction in the EU: A descriptive analysis. Poverty and Public Policy, 1(2), 1-49. https://doi.org/10.2202/1944-2858.1023

Caminada, K., Goudswaard, K., \& Koster, F. (2012). Social income transfers and poverty: a cross-country analysis for OECD countries. International Journal of Social Welfare, 21(2), 115-126. https://doi. org/10.1111/j.1468-2397.2011.00815.x

Chzhen, Y. (2014). Child poverty and material deprivation in the European Union during the Great Recession. Innocenti Working Paper, 2014-06. Florence: UNICEF.

Chzhen, Y., Bruckauf, Z., \& Toczydlowska, E. (2017). Sustainable Development Goal 1.2: Multidimensional child poverty in the European Union. Working Paper, 2017-07. Florence: UNICEF.

EC (2014). Common Basic Principles for Immigrant Integration Policy in the EU. Retrieved from https:// ec.europa.eu/migrant-integration/librarydoc/common-basic-principles-for-immigrant-integration-policy-in-the-eu

Ette, A., \& Faist, T. (2007). The Europeanization of national policies and politics of immigration: Research, question and concepts. In T., Faist \& A., Ette (Eds.) The Europeanization of national policies and politics of immigration. Between autonomy and the European Union (pp. 3-31). New York, NY: Palgrave Macmillan.

Eurofound (2017). In-work poverty in the EU. Luxembourg: Publications Office of the European Union.

EC (2008). Joint Report on Social protection and social inclusion 2008. Social inclusion, pensions, healthcare and long-term care. Luxembourg: Office for Official Publications of the European Communities.

Eurostat (2017). Migrant integration, 2017 edition. Luxembourg: Publications Office of the European Union.

Eurostat (2020). Migration and migrant population statistics. Statistics explained. Retrieved from https://ec.europa.eu/eurostat/statistics-explained/index.php/Migration_and_migrant_population statistics

Favell, A., \& Recchi, E. (2011). Social Mobility and Spatial Mobility. In A., Favell \& V., Guiraudon (Eds.) Sociology of the European Union (pp. 50-75). New York, NY: Palgrave Macmillan.

Findlay, A., Geddes, A., \& McCollum, D. (2010). International migration and recession. Scottish Geographical Journal, 126(4), 299-320. https://doi.org/10.1080/14702541.2010.549346

Förster, M. F., \& Mira D'Ercole, M. (2005). Income Distribution and Poverty in OECD Countries in the Second Half of the 1990s. Working Paper, 22. Paris: OECD Social, Employment and Migration. https:// doi.org/10.1787/1815199x

Fromentin, V., Damette, O., \& Zou, B. (2017). The Global Economic Crisis and the Effect of Immigrant Workers on Native-Born Employment in Europe. The World Economy, 40(6), 1068-1088. https://doi. org/10.1111/twec.12394

Geddes, A. (2003). The Politics of Migration and Immigration in Europe. London: Sage.

Gilmartin, M., \& Dagg, J. (2018). Immigrant integration and settlement services in Ireland. Project Report. Irish Research Council. 
Grzymala-Kazlowska, A., \& Phillimore, J. (2017). Introduction: rethinking integration. New perspectives on adaptation and settlement in the era of super-diversity. Journal of Ethnic and Migration Studies, 44(1), 179-196. https://doi.org/10.1080/1369183X.2017.1341706

Guio, A. C., Gordon, D., Najera, H., \& Pomati, M. (2017). Revising the EU material deprivation variables. 2017 edition. Eurostat Statistical Working Papers. Luxembourg: Publications Office of the European Union.

Guio, A. C., Gordon, D., Marlier, E., Najera, H., \& Pomati, M. (2018). Towards an EU measure of child deprivation. Child Indicators Research, 11(3), 835-860. https://doi.org/10.1007/s12187-017-9491-6

Guio, A. C., Marlier, E., Vandenbroucke, F., \& Verbunt, P. (2020). Micro-and macro-drivers of child deprivation in 31 European countries. Eurostat Statistical Working Papers. Luxembourg: Publications Office of the European Union.

Hagelund, A., \& Kavli, H. C. (2017). Integration. In B., Greve (Ed.). Handbook of Social Policy Evaluation (pp. 383-402). Cheltenham: Edward Elgar Publishing.

Hooijer, G., \& Picot, G. (2015). European welfare states and migrant poverty: The Institutional Determinants of Disadvantage. Comparative Political Studies, 48(14), 1879-1904. https://doi. org/10.1177/0010414015597508

Huddleston, T., Bilgili, Ö., Joki, A. L., \& Vankova, Z. (2015). Migrant integration policy index 2015. Barcelona/Brussels: CIDOB, MPG.

Huddleston, T., Niessen, J., \& Tjaden, J. T. (2013). Using EU indicators of immigrant Integration: Final Report for Directorate-General for Home Affairs. Brussels: Home Affairs, European Commission.

Huddleston, T., Niessen, J., Ni Chaoimh, E., \& White, E. (2011). Migrant Integration Policy Index. British Council and Migration Policy Group.

IOM (2012). IOM and migrant integration. Geneva: International Organisation for Migration.

Kaczmarek-Firth, A., \& Dupré, D. (2018). Measuring material deprivation at individual level and measuring children material deprivation. Working Paper, 24. United Nations Economic Commission for Europe, Conference of European Statistics. Expert meeting on measuring poverty and inequality 29-30 November 2018, Austria.

Kasimis, C., \& Papadopoulos, A. G. (2012). Employment and occupational mobility of migrants in two local labour markets [in Greek]. In C., Kasimis \& A. G., Papadopoulos (Eds.) Migrants in Greece: employment and integration in local societies (pp. 289-326). Athens: Alexandreia.

Klarenbeek, L. (2019). Relational Integration: A Response to Willem Schinkel. Comparative Migration Studies, 7. https://doi.org/10.1186/s40878-019-0126-6

Marlier, E., Atkinson, A. B., Cantillon, B., \& Nolan, B. (2007). The EU and Social Inclusion: Facing the Challenges. Bristol: Policy Press.

Martiniello, M. (2006). Towards a coherent approach to immigrant integration policy(ies) in the European Union. Retrieved from http://www.oecd.org/dev/38295165.pdf

Michailakis, D., \& Reich, W. (2009). Dilemmas of inclusive education. ALTER, European Journal of Disability Research, 3(1), 24-44. https://doi.org/10.1016/j.alter.2008.10.001

Miežienè, R., \& Krutulienè, S. (2019). The Impact of Social Transfers on Poverty Reduction in EU Countries. Baltic Journal of European Studies, 9, 157-175. https://doi.org/10.1515/bjes-2019-0009

OECD/EU (2018). Settling In 2018: Indicators of Immigrant Integration. Paris, Brussels: OECD Publishing. European Union. https://doi.org/10.1787/9789264307216-en

Oliver, C., \& Gidley, B. (2015). Integration of Migrants in Europe. Centre on Migration, Policy, and Society. Retrieved from https://www.compas.ox.ac.uk/wp-content/uploads/OSIFE15-Report.pdf

Otto, A. (2018). Social expenditure, social rights, and benefit receipt as indicators of welfare state generosity: Three peas in a pod, or a different kettle of fish altogether? International Journal of Sociology and Social Policy, 38(9/10), 851-867. https://doi.org/10.1108/IJSSP-02-2018-0022

Papadopoulos, A. G. (2016, January 8). From migration crisis to refugee crisis in Europe: Securitization priorities vs. what? Hellenic Observatory Seminar, London School of Economics and Political Science.

Penninx, R. (2019). Problems of and solutions for the study of Immigrant Integration. Comparative Migration Studies, 7. https://doi.org/10.1186/s40878-019-0122-x

Penninx, R., \& Garcés-Mascareñas, B. (2016). The Concept of integration as an analytical tool and as a policy concept. In: B., Garcés-Mascareñas, \& R., Penninx (Eds.). Integration processes and policies 
in Europe: Contexts, Levels and Actors (pp. 11-29). Cham: Springer. https://doi.org/10.1007/978-3319-21674-4_2

Phillimore, J. (2012.) Implementing integration in the UK; lessons for theory, policy and practice. Policy and Politics, 40(4), 525-545. https://doi.org/10.1332/030557312X643795

Recchi, E. (2016). The Citizenship Gap in European Societies: Conceptualizing, Measuring and Comparing 'Migration Neutrality' across the EU. International Migration, 54(6), 181-200. https://doi. org/10.1111/imig.12292

Römer, F. (2017). Generous to all or 'insiders only'? The relationship between welfare state generosity and immigrant welfare rights. Journal of European Social Policy, 27(2), 173-196. https://doi. org/10.1177/0958928717696441

Ruhs, M., Tamas, K., \& Palme, J. (2019). Bridging the Gaps: Linking Research to Public Debates and Policy-Making on Migration and Integration. Oxford: Oxford University Press.

Scipioni, M., \& Urso, G. (2017). Migration policy indexes. Ispra: JRC.

SPC (2018). Annual Report 2018. Review of the social protection performance monitor and development in social protection policies. Report on key social challenges and main messages. Social Protection Committee. Luxembourg: Publications Office of the European Union, 2018.

TARKI (2011). Child Well-being in the European Union: Better Monitoring Instruments for Better Policies. Budapest: TARKI Social Research Institute.

Tilly, C. (2011). The impact of the economic crisis on international migration: a review. Work, Employment \& Society, 25(4), 675-692. https://doi.org/10.1177/0950017011421799

Waters, M. C., \& Pineau, M. G. (Eds.) (2015). The Integration of Immigrants into American Society. National Academies of Sciences, Engineering, and Medicine. Washington, DC: The National Academies Press. https://doi.org/10.17226/21746

Wiesbrock, A. (2013). Sources of law, regulatory processes and enforcement mechanisms in EU migration policy: The slow decline of national sovereignty. Maastricht Journal of European and Comparative Law, 20(3), 423-441. https://doi.org/10.1177/1023263X1302000306

Zetter, R., Griffiths, D., Sigona, N., Flynn, D., Pasha, T., \& Beynon, R. (2006). Immigration, social cohesion and social capital: What are the links? York: Joseph Rowntree Foundation. 


\section{GUIDE FOR AUTHORS}

Manuscripts, in the English language, should be submitted to the Secretary of EUROPA XXI (Institute of Geography and Spatial Organization, Polish Academy of Sciences, Twarda 51/55, 00-818 Warsaw, Poland; b.szejgiec@twarda.pan.pl or Europa.XXI@twarda.pan.pl).

The manuscripts should be arranged in the following order. First sheet: title, full name of author(s), affiliation, full postal address, e-mail address. Second sheet: abstract of no more than 100 words, key words (3-10) at the end of the abstract. Subsequent sheets: the main text of $5,000-8,000$ words (no more than 10,000 words). The main text may be organized in sections under appropriate headings without numerals.

References should be printed in alphabetical sequence at the end of the text, according to the APA style with DOI (if possible), or in case of Internet available documents - website address (Retrieved from...).

Examples:

- Articles from journals:

Törnqvist, G. (2004). Creativity in time and space. Geografiska Annaler. Series B. Human Geography, 86(4), 227-244. https://doi.org/10.1111/j.0435-3684.2004.00165.x

- Books:

Pacione, M. (2001). Urban geography. A global perspective. London-New York: Routledge.

- Chapters:

Haworth, E.Y., \& Hurley, M.A. (1984). Comparison of the stelligeroid taxa of the centric diatom genus Cyclotella. In M., Ricard (Ed.). Proceedings of the 8th International Diatom Symposium (pp. 43-58). Paris-Koenigstein: Koeltz Scientific Books.

- Unpublished documents (theses, 'grey literature'):

Kohno, A., Stubblefield, A., Rubin, A.D., \& Wallach, D.S. (2004). Analysis of an electronic voting systems. Johns Hopkins University Information Security, 23 pp. (typescript)

- Electronic and Internet documents or websites:

CIT (2012, December 20). NASA Jet Propulsion Laboratory. California Institute of Technology. Retrieved from http://www.jpl.nasa.gov/

References should be indicated in the text by listing, in parenthesis, the authors name followed by the data of publication, e.g. (Haeberli, 1975; Pacione, 2001) or (Haworth \& Hurley, 1984) or (Boudevillain et al., 2009) if there are more than six authors (Note: all the authors should be listed in the references).

Footnotes and notes should be referred to by superscript letters.

Illustrations should be supplied in one of the following formats, in black and white (for printing) and additionally in colours (to be published in Internet):

- photographs: JPG, TIFF, EPS or PSD,

- maps, figures and diagrams should be presented as vector files in $\mathrm{Al}$ (Adobe Illustrator) or one of the format mentioned above. 
Please ensure that the resolution is not lower than $300 \mathrm{dpi}$ and the lines are a minimum of 0.3 points thick.

Tables should be prepared on separate sheets and numbered sequentially with Arabic numerals (e.g. Table 1). Each table should be provided with a clear descriptive caption at the top and informative column headings.

Equations and symbols used in mathematical formulae must be clearly explained. Axes on graphs should be described clearly. Units and abbreviations used by authors should conform to the International List. Measurements should be given in metric units.

Articles accepted for publication in EUROPA XXI are not honoured financially. Authors of accepted articles will receive one copy of the journal free of charge.

Authors are responsible for indicating copyright as well as permission from the copyright holder to reproduce any texts, tables or illustrations for which copyright exists. 